\title{
Brief Communication: Use of multicopter drone optical images for landslide mapping and characterization
}

\author{
Guglielmo Rossi ${ }^{1}$, Luca Tanteri ${ }^{1}$, Veronica Tofani ${ }^{1}$, Pietro Vannocci ${ }^{1}$, Sandro Moretti ${ }^{1}$, Nicola Casagli ${ }^{1}$ \\ $5 \quad{ }^{1}$ Department of Earth science, University of Florence, Via La Pira 4, 50121, Italy \\ Correspondence to: Veronica Tofani (veronica.tofani@unifi.it)
}

\begin{abstract}
The Department of Earth Sciences of Florence (DST) has developed a new type of drone chassis., Several survey campaigns were performed in Ricasoli village, in the Upper Arno river Valley (Tuscany, Italy) with the drone equipped with an optical camera, to understand the possibility of this rising technology to map and to characterize landslides. The aerial RGB images were analysed and combined using SfM (Structure from Motion) software. The comparative analysis of the obtained DTMs allowed an accurate reconstruction and mapping of the detected landslides. The collected data also allowed to precisely detect some slope portions prone to failure and to evaluate the area and volume of the involved masses.
\end{abstract}

\section{Introduction}

Mapping and displacement monitoring of unstable slopes is a crucial tool for the hazards prevention and assessment.

15 The remote sensing techniques are effective tools to obtain spatially-distributed information on kinematics (Delacourt et al., 2007), and can be operational from spaceborne, airborne and ground-based platforms. The main advantage of monitoring using remote sensing techniques is the capability to acquire spatially continuous data, even with centimetric precision, that can be very useful when integrated with the punctual measurements of the conventional ground-based techniques (Tofani et al., 2012).

20 Nevertheless, remote sensing analysis performed using aerial and satellite platforms highlights some drawbacks, mainly related to the high costs and the difficult repeatability in a short time.

In the last decade, the combination between a rapid development of low cost and small Unmanned Aerial Vehicles (UAVs) with improved battery technology and the recent improvements of conventional sensors (Optical and LiDAR) in terms of cost and dimensions, lead to new interesting scenarios in environmental remote sensing and surface modelling and

25 monitoring with this equipment (Colomina and Molina, 2014; Travelletti et al., 2012;James and Robson, 2012; Remondino et al., 2011; Eisenbeiss and Sauerbier, 2011; Fabris and Pesci, 2005). As an important mean of obtaining spatially distributed data, UAV-based remote sensing has the following advantages: real-time applicability, flexible survey planning, highresolution, low cost, and it can collect information in dangerous environments without risk (Chang Chun et al., 2011).

In the last few years UAVs, equipped with optical cameras to perform digital aerial photogrammetry, have been applied to study landslides (Balek \& Blahut, 2015; Marek et al., 2015; Peternel et al., 2016; Mateos et al., 2016; Rossi et al, 2016). 
Nat. Hazards Earth Syst. Sci. Discuss., doi:10.5194/nhess-2017-46, 2017

Manuscript under review for journal Nat. Hazards Earth Syst. Sci.

Discussion started: 13 February 2017

(c) Author(s) 2017. CC-BY 3.0 License.

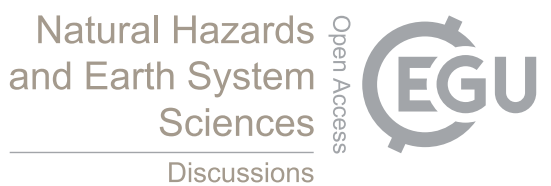

(c) $\underset{\mathrm{BY}}{(i)}$

Digital photogrammetry technique is, indeed, a technique that permits to reconstruct a 3D surface model by using algorithms that can provide 3D spatial information from features and elements visible in two or more images acquired from different points of view.

Once images are oriented and, possibly, calibrated with sensor and lens data, it is possible to obtain very high-definition

5 point clouds (Colomina \& Molina, 2014), along with Digital Surface Models (DSM), orthophotos and accurate 3D representation of objects or surfaces.. This process is generally carried out using one of the numerous Structure-FromMotion (SfM) software packages, that can compute the 3D data from a series of overlapping, offset images (Westoby et al., 2012). 'Structure-from-Motion' processing is based on specific algorithms for feature-matching and bundle-adjustment, allowing also to estimate automatically the internal camera corrective parameters..

10 The time and cost-effectiveness of the technique make it possible to repeat measurement surveys at regular time intervals to monitor the changes occurred between different acquisitions, by comparing the resulting digital models.

In this work a multicopter drone named Saturn, developed by the research team of the Department of Earth Science at the University of Florence, equipped by a consumer-grade optical camera, is used to carry out photogrammetric data acquisition in an area close to the village of Ricasoli, in Tuscany (Italy), strongly affected by active landslides. Multiple

15 photogrammetrical surveys were performed using the Saturn drone to provide multitemporal 3D models of the slope.

The aim of the work is to test the applicability and to validate the first preliminary results of the newly developed drone as well as to create high-resolution 3D surface models to better characterize and to monitor the landslides affecting the village.

\section{Study site}

Ricasoli is a small village located in the Upper Arno river Valley (Tuscany), an area strongly subjected to diffuse slope instability phenomena. The village is located in intramontane basin with a NW-SE orientation, that it has been formed during the extensional phase of the Neogene-Quaternary evolution of the Tyrrhenian side of the Northern Apennines (Abbate, 1983).

Over the substrate of the basin that is composed of flysh-type formations; Cervarola-Falterona Unit on the eastern side and Macigno Formation on the western side, fluvial-lacustrine sediments have been deposited in this area in three phases 25 between Lower Pliocene and Upper Pleistocene (Fidolini et al., 2013).

From a geomorphological point of view Ricasoli is located on morphological high made of fluvial-lacustrine sediments overlaid with fluvial sediments (figure 1). Fluvial-lacustrine sediments are mainly made of silts, clays and peaty clays (Terranova Silt TER and Ascione Stream Clay, ASC) while fluvial sediments are constituted by silts, sands and gravels (namely Silt and Sand of Oreno Stream LSO, Casa La Loccaia Sands LOC, Latereto silt LAT) (Rosi et al., 2013).

30 The slopes surrounding the hill of Ricasoli are affected by numerous landslides, which cause the retreat of the escarpments of the village, involving infrastructures and buildings. 
Nat. Hazards Earth Syst. Sci. Discuss., doi:10.5194/nhess-2017-46, 2017

Manuscript under review for journal Nat. Hazards Earth Syst. Sci.

Discussion started: 13 February 2017

(c) Author(s) 2017. CC-BY 3.0 License.

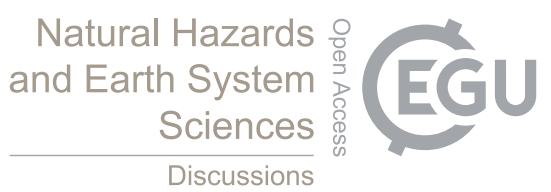

(c) (i)

Different types of landslides affect the village of Ricasoli. Falls, topples and shallow landslides affect the slopes surrounding the village. These are made of sands and sandy silts with high slope degrees. Moving downslope the cohesive soils substitute granular materials and, slope degree decreases and compound rotational slides develop (Figure 1).

The diffuse sliding phenomena, generally triggered by heavy and continuous rainfalls, are causing a progressive retreat of 5 the escarpments.

Since 2004 several monitoring instruments have been installed; inclinometers, extonsometers, crackmeters in the buildings of the village. At the same time terrestrial laser scanner (TLS) surveys have been carried out.

In 2014 consolidation works have been realized in the northern flank of the village that according to the monitoring results is the more active. In particular slope reshaping and consolidation using wooden poles were realized.

10 The study is particularly focused on the eastern part of northern slope, where two new shallow landslides occurred respectively in March the $1^{\text {st }}$ (Landslide 1, LS1) and March the $30^{\text {th }} 2016$ (Landslide 2, LS2) after intense rainfalls (Figure 2) involving a portion of the superficial recent landfill and underlying in situ soils formations. These events occurred after a period of intense rainfall as reported in Figure 2.

\section{Materials and methods}

\section{$15 \quad 3.1$ The multicopter drone}

The more commonly used multicopter drones have a "spider" structure with a central body, holding the flight control units, and many radial arms, as support for the propulsion devices.

Aimed to improve the structure of the existing multicopters, the Department of Earth Sciences of Florence (DST) has developed a new type of chassis, that allows to overcome some critical issues in carrying scientific and heavy payload or in applications requiring long flight autonomy. (Figure 3a). It is an innovative perimetral chassis that fully supports flight dynamics (Figure 3a), currently patented in Italy, protected by PCT (Patent Cooperation Treaty) applied in 117 countries in the world and patent pending in USA and all Europe countries.

The drone was named Saturn, and its improved structure has these main key features:

- Increased space without constraints to positioning electronics, flight system and instruments.

- The central payload area can be connected in a rigid manner or even with a flexible mount to dramatically cut down mechanical vibrations from the propulsion system without compromise flight dynamics and performance.

- Maximized flexibility of propulsion configuration with a single chassis: without any modifications to the chassis it is possible to vary the number of propulsion systems (three, four, six etc..) even during the flight.

- The flexible propulsion configuration allows us to fit the need of every single mission: less engine to increase autonomy, more engine to allow for heavy payload. 
Nat. Hazards Earth Syst. Sci. Discuss., doi:10.5194/nhess-2017-46, 2017

Manuscript under review for journal Nat. Hazards Earth Syst. Sci.

Discussion started: 13 February 2017

(c) Author(s) 2017. CC-BY 3.0 License.

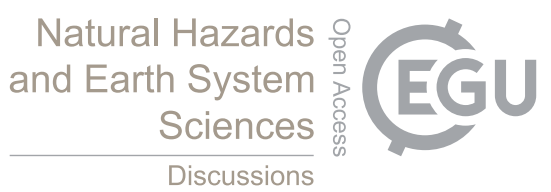

- Variable propulsion geometry to keep the perfect balance with all types of payloads and to manage an emergency landing in case of a propulsion unit failure.

- Completely rain proof electrical and electronic systems to fly during any weather condition.

The Saturn drone is capable of autonomous flight, from take-off to landing, and emergency management. The autopilot

5 software is completely programmable and configurable.

Saturn drone has onboard a complete and fully configurable acquisition system with frame grabber for scientific instruments. The drone is a "light" UAV class ( $<25 \mathrm{~kg}$ take off weight), can hover until 30 minutes and have a useful load of $10 \mathrm{~kg}$.

\subsection{Digital photogrammetric surveys}

10 The three aerial photogrammetric surveys were performed (see Table 1), respectively on July $30^{\text {th }} 2015$, March $2^{\text {nd }} 2016$ and April $6^{\text {th }} 2016$ using the DST drone Saturn, equipped with a Sony digital RGB photocamera with 8 MPix resolution, mounted on a gimbal fully designed and assembled ad-hoc by the research team of the Department of Earth Science.

The photogrammetric surveys were performed in 5 different stages: (1) mission planning, (2) acquisition of ground control points with GPS, (3) flight and image acquisition, (4) point-cloud processing and refinement and (5) implementation in GIS

15 environment (Figure 3).

The first stage consists in the flight planning, that must ensure the best coverage of the target area with an optimal photo overlap in frontal (overlap) and lateral direction (sidelap), considering the camera footprint at the desired flight altitude (Figure 3b). To optimise flight time, spatial coverage and ground resolution the multicopter drone was programmed to fly at a constant altitude of around $70 \mathrm{~m}$ a.g.l. from the top of the slope, with side overlap and front overlap respectively set to $50 \%$

20 and $60 \%$ in order to guarantee optimal conditions for the tie-points detection algorithm and camera alignment (bundle adjustment)..

Objects on the ground that can be easily recognized in the aerial photos were georeferenced with a GPS (Leica 1200 series) and used as Ground Control Points (GCPs) (Figure 3c ): a special care was taken to have a homogeneous spatial distribution of GCPs on the scene. The images were processed using Agisoft Photoscan Professional (Agisoft LLC, 2016) software and

25 the resulting data were implemented in GIS environment using the ESRI ArcGIS package. (Figure 3d and Figure 3e).

Nevertheless, the scene was mainly characterized by low vegetation and grass and was decided to integrate natural CGPs with some artificial markers, placed on the ground during each flight and georeferenced with centimetric accuracy (generally less than $0.03 \mathrm{~m}$ in XYZ).

The original point clouds were opportunely filtered using Photoscan tools, allowing to detect and remove the points

30 corresponding to vegetation. This step was necessary since the grass growth generated an irregular positive offset of 20-40 centimeters, along the whole scene, between the first and the third survey.

The ground image coverage obtained by aerial survey is shown in Figure 3b; the maximum coverage is in correspondence of the lower part of the escarpment, where every point of the scene is visible in more than 9 images. 
Nat. Hazards Earth Syst. Sci. Discuss., doi:10.5194/nhess-2017-46, 2017

Manuscript under review for journal Nat. Hazards Earth Syst. Sci.

Discussion started: 13 February 2017

(c) Author(s) 2017. CC-BY 3.0 License.

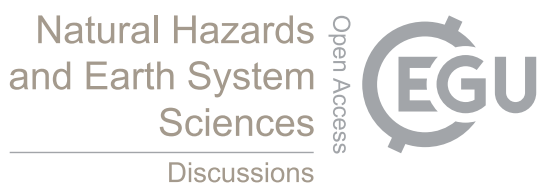

Further details on the aerial survey are reported in Table 1.

The resulting digital orthomosaics were processed at a ground resolution of $\sim 5 \mathrm{~cm} /$ pix and the $3 \mathrm{D}$ point clouds were composed by up to 100 million points (Figure 3d). Furthermore, high-resolution DTMs $(0.05 \mathrm{~m} /$ pix) were obtained by using the point clouds, appropriately filtered to remove all the points processed on buildings, unwanted elements on the scene and

5 high vegetation.

\section{Results}

The data collected in the three photogrammetric surveys were analyzed and compared each other in order to assess the accuracy of the resulting digital models and precisely detect areas affected by instability processes.

The comparison was performed using both the orthomosaics resulting by the photogrammetric processing and DTMs derived

10 by the point clouds.

The DEMs were compared to detect any morphological change between the three acquisitions, permitting to characterize the landslide and, in addition, to precisely point out geomorphological features of landslide-prone areas on the slope.

The result of the first aerial survey carried out on July the $30^{\text {th }} 2015$ shows an incipient deformation on the ground surface (yellow dashed circle in Figure 4a) on the eastern part of the slope. During a preliminary survey, we assessed that such part

15 of the slope was stabilized only using wooden poles, anchored at a low depth, that appeared bended downslope, with tension cracks and a little sink uphill. This incipient movement phenomenon is indicated as pre-existing LS1 in Figure 4a. No other indicators of ongoing movement were detected on the remaining part of the northern slope during the first flight.

As a consequence of intense rainfalls occurred during February 2016 the area that was recognized as potentially instable by the first survey was involved in a shallow landslides, affecting a portion of the slope with an overall extent of $1250 \mathrm{~m}^{2}$ (LS1

20 in Figure $4 b)$.

The comparison between the first and second survey DTMs carried out on March the $1^{\text {st }} 2016$ (Figure 4d)) permits to highlight respectively the detachment, the transport and the deposition areas of LS1 and an appreciable displacement, with the development of two new scarps, on the eastern part of the slope ( $2 a$ and $2 b$ in Figure $4 d$ ). The two scarps indicate a new landslide that was involving a portion of a private property nearby. Such landslide (LS2) finally occurred in March the $9^{\text {th }}$

2016 after a few days of intense rainfall and appears visible by comparing the DTMs of the second and the third survey that was carried out on April the $6^{\text {th }} 2016$.

The evolution of the superficial topography was also studied by extracting surface profiles along two selected sections (AA' and BB' as shown in Figure 4).

The longitudinal profiles (Figure 4) show the general geometry of the landslides. In the detachment area LS1 appears as characterized by a nearly planar slip-surface, with an average depth of $60-70 \mathrm{~cm}$ from the original topography, visible in the detachment area, with an extent of $480 \mathrm{~m}^{2}$, involving mainly a superficial level of artificial landfill, put in place during previous slope stabilization works. 
Nat. Hazards Earth Syst. Sci. Discuss., doi:10.5194/nhess-2017-46, 2017

Manuscript under review for journal Nat. Hazards Earth Syst. Sci.

Discussion started: 13 February 2017

(c) Author(s) 2017. CC-BY 3.0 License.

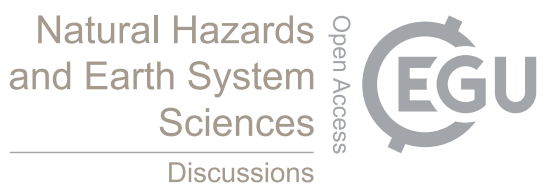

Furthermore, within LS1 a new scarp was detected by comparing the DTMs of the second and third surveys (scarp $1 d$ in Figure 4). This scarp was also verified during a field survey and it partially delimits a secondary slope movement that involves the lower part of the landslide LS1. The movement of this portion was observed through a comparison between the DTMs and the orthophotos, with average superficial displacement of 0,6 meters along the slope and resulting in an

5 advancement of the landslide toe of around $50 \mathrm{~mm}$, as measured during a field inspection.

Substantial changes in elevation of up to 0,6 meters are visible only in the part immediately downslope the scarp $1 d$ (Figure $4 \mathrm{f})$, the rest of the moving portion do not show appreciable elevation differences.

The extent of such secondary landslide is $\sim 430 \mathrm{~m}^{2}$, and it is characterized by a planar translational type of movement (Varnes, 1978) with an average thickness of $\sim 0,5-0,6 \mathrm{~m}$, also involving part of the antecedent LS1 deposits.

10 The LS2, as visible from the BB' profile in Figure 4 has a different geometry. In fact, it was composed by two rototranslational landslides that evolved in flow type landslides, creating a deposition area at the slope toe.

Thanks to the DEMs comparison it has been possible to estimate the total extent and volume, both including detachment and depositions zones, of LS1 and LS2. Extents for LS1 and LS2 are, respectively, $1250 \mathrm{~m}^{2}$ and $320 \mathrm{~m}^{2}$ while volumes are 480 $\mathrm{m}^{3}$ and $70 \mathrm{~m}^{3}$ respectively.

\section{5. Discussions}

The aim of the work was to test the applicability and evaluate the potential of the use of drones, in this case equipped with a commercial RGB camera, to detect and possibly monitor mass movement on slopes.

The comparison between the obtained DTMs permitted to map and to characterize the mass movements on the northern slope of Ricasoli.

20 Although this is a preliminary work, focused on a small area, it was sufficient to point out some advantages and drawbacks of the technique.

One of the advantages is the potential repeatability of the surveys in a relatively short time and with high resolution, especially when compared to other techniques such as Terrestrial Laser Scanning, and their low costs. Indeed, in most of cases, in-situ elements can be easily used as GCPs while at least a few artificial reflectors must be installed for a TLS survey,

25 a time-consuming procedure that must be repeated every time. Furthermore, performing remote sensing surveys using a drone permits to acquire data with high resolution and precision over wider areas in a small time and reducing the "shaded areas". The total time for the survey in the area covered (around $0,02 \mathrm{~km}^{2}$ ) is about 40 minutes, including flight planning and GCPs acquisition with GPS. Moreover, it allows to immediately processing an aerial orthomosaic, very useful for visual inspections, characterization and mapping of the detected phenomena even in emergency contexts.

30 Nevertheless, this work pointed out one of the most important drawbacks of this kind of aerial photogrammetric applications; the difficulty to remove vegetation from the $3 \mathrm{D}$ models. 
Nat. Hazards Earth Syst. Sci. Discuss., doi:10.5194/nhess-2017-46, 2017

Manuscript under review for journal Nat. Hazards Earth Syst. Sci.

Discussion started: 13 February 2017

(c) Author(s) 2017. CC-BY 3.0 License.

The vegetation is generally removed by the resulting point clouds using opportune filtering algorithms (Brodu et al. 2012) that could be based on the relative position between the points within a certain distance at a certain scale, on the RGB values or, at least, manually. The application of such techniques and automatic algorithms is often effective when using laser scanning data, thanks to the capability of the laser beams to penetrate the vegetation foliage, but less effective on

5 photogrammetric point clouds, especially in presence of dense and uniform coverage. As seen in this work, the result of this effect is the impossibility of reconstruct precisely the terrain features below a dense grass coverage on the slope, increased from the first survey (July 2015) to the last one. In particular, as visible in Fig. 4b and Fig. 4c, during the second and third surveys, the slope was covered by a dense grass blanket that prevented to triangulate points corresponding to the surface below. This effect resulted in a diffuse increase in altitude in all the grassy areas (from 20 to $30 \mathrm{~cm}$ ), visible from the DEM

10 comparison. Removing these points would lead to have widespread holes in the 3D model. On the other hand, isolated trees or sparser vegetation are generally easily removed by applying automatic filters and a manual refinement.

In this case, as well as leading to an uncertain volume calculation, such vegetation effect did not allow to detect fissures and other features of the ground, useful for precise landslide delimitation and characterization.

However, the contribute of the vegetation can be significantly reduced with the use of a high-quality camera with higher

15 resolution and equipped with low distortion lenses, avoiding fish-eye effects.

Generally, although pointing out the good potential of drone applications for mapping and characterization of rapid kinematic landslides, this work highlighted a strong need for a higher frequency of surveys and for the integration with other monitoring technique, due to the temporal discontinuity of the measurements.

A future development will regard the execution of further drone surveys, also using different types of sensors and the

20 application of software that permit to reconstruct the displacement vectors, based on the acquired point clouds, DTMs or on the RGB images.

\section{Conclusions}

In the last decade, the combination of rapid development of low cost and small Unmanned Aerial Vehicles (UAVs), improved battery technology and conventional sensors (Optical and LiDAR) in terms of cost and dimensions, led to new

25 opportunities in environmental remote-sensing and 3D surface modelling. The Department of Earth Sciences of the University of Firenze has developed a new drone chassis that allows to overcome some critical issues for scientific and heavy payload or long flight applications. This new drone has been equipped with an optical camera and it has been used to perform photogrammetric data acquisition in an area close to the village of Ricasoli, in Tuscany (Italy). The aim of this work is to test the use of multicopter drone measurements for landslide detection and characterization. The images acquired during

30 the aerial drone surveys allowed us to obtain a continuous 3D surface model of the studied area using a photogrammetric approach. 
Nat. Hazards Earth Syst. Sci. Discuss., doi:10.5194/nhess-2017-46, 2017

Manuscript under review for journal Nat. Hazards Earth Syst. Sci.

Discussion started: 13 February 2017

(c) Author(s) 2017. CC-BY 3.0 License.

The detection of possible displacements occurred in the covered area between three aerial surveys was performed by comparing the different Digital Terrain Models and point clouds. As a result, two mass movement were detected and characterized, namely LS1 and LS2, affecting the northern slope of Ricasoli village, and a new incipient phenomenon in the lower part of LS1.

5 The drone survey has proven to be an easier and more cost- and time- effective approach with respect to other techniques. Thanks to these potentialities and to its repeatability, drone surveys will become an integral part of the monitoring system in Ricasoli village.

\section{Acknowledgements}

This work was carried out to evaluate the potentialities of the new Saturn drone, entirely designed and developed at the

10 Department of Earth Sciences of the University of Florence. Among the personnel of the department, authors want to gratefully thank Gabriele Scaduto and Teresa Salvatici for the logistic support during the surveys in Ricasoli. Moreover, heartfelt thanks to Massimiliano Nocentini and Luca Lombardi, for the precious historical information about slope instability in Ricasoli.

\section{References}

15 Aman, A. A. and Bman, B. B.: The test article, J. Sci. Res., 12, 135-147, doi:10.1234/56789, 2015.

Aman, A. A., Cman, C., and Bman, B. B.: More test articles, J. Adv. Res., 35, 13-28, doi:10.2345/67890, 2014.

Abbate E.: Fluvial-Lacustrine Deposits of the Upper Valdarno. C.N.R., Firenze, 1983.

Agisoft LLC: Agisoft PhotoScan Professional v. 1.2.4, available at http://www.agisoft.com/

Balek J, Blahut J.: A critical evaluation of the use of an inexpensive camera mounted on a recreational unmanned aerial vehicle as a tool for landslide research. Landslides, first online, 2016.

Brodu N and Lague D.: 3D terrestrial lidar data classification of complex natural scenes using a multi-scale dimensionality criterion: Applications in geomorphology. ISPRS Journal of Photogrammetry and Remote Sensing 68: 121-134, 2012

Chang-chun L., Guang-Sheng Z., Tian-jie L., A-du G.: Quick image-processing method of UAV without control points data in earthquake disaster area. Trans. Nonferrous Met. Soc. China 21: 523-528, 2011.

25 Colomina I., Molina P.:, Unmanned aerial systems for photogrammetry and remote sensing: A review. ISPRS Journal of Photogrammetry and Remote Sensing, 92: 79-97, 2014.

Cruden D. M. and Varnes D.J.:. Landslide Types and Processes. A. K. Turner and R. L. Schuster, Eds., Landslides: Investigation and Mitigation: Sp. Rep. 247, National Academy Press, Washington DC, pp. 36- 75, 1996.

Delacourt C., Allemand P., Berthie, E., Raucoules D., Casson B., Grandjean P., Pambrun C., Varel E.: Remote-sensing techniques for analysing landslide kinematics: a review. Bulletin de Societe Geologique 178 (2): 89-100, 2007. 
Nat. Hazards Earth Syst. Sci. Discuss., doi:10.5194/nhess-2017-46, 2017

Manuscript under review for journal Nat. Hazards Earth Syst. Sci.

Discussion started: 13 February 2017

(c) Author(s) 2017. CC-BY 3.0 License.

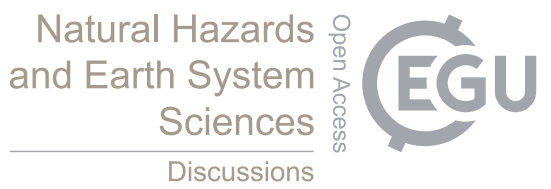

Eisenbeiss H. and Sauerbier M.: Investigation of uav systems and flight modes for photogrammetric applications. The Photogrammetric Record 26(136): 400-421, 2011.

Fabris M. and Pesci A. :Automated DEM extraction in digital aerial photogrammetry: precisions and validation for mass movement monitoring” Annals of Geophysics, 48 (6), 2005.

5 James M. R. and Robson S. : Straightforward reconstruction of 3D surfaces and topography with a camera: Accuracy and geoscience application. Journal of Geophysical Research,117, f03017, doi:10.1029/2011jf002289, 2012.

Marek L., Miřijovský J., Tuček P. : Monitoring of the Shallow Landslide Using UAV Photogrammetry and Geodetic Measurements. In: Lollino G. et al. (eds) Engineering Geology for Society and Territory - Volume 2. Springer, 2015.

Mateos R.M., Azañón J.S., Roldán F.J., Notti D., Pérez-Peña V., Galve J.P., Pérez-García J.L., Colomo C.M., Gómez-López

10 J.M., Montserrat O., Devantèry N., Lamas-Fernández F., Fernández-Chacón F.: The combined use of PSInSAR and UAV photogrammetry techniques for the analysis of the kinematics of a coastal landslide affecting an urban area (SE Spain). Landslides, first online, 2016.

Peternel T., Kumelj S., Ostir K., Komac M.: Monitoring the Potoška planina landslide (NW Slovenia) using UAV photogrammetry and tachymetric measurements. Landslides, first online, 2016.

15 Remondino F., Barazzetti L., Nex F., Scaioni M., Sarazzi D.: Uav photogrammetry for mapping and 3d modeling - current status and future perspectives-. International Archives of the Photogrammetry, Remote Sensing and Spatial Information Sciences, Volume XXXVIII-1/C22, 2011, ISPRS Zurich 2011 Workshop, 14-16 September 2011, Zurich, Switzerland, 2011.

Rosi A., Vannocci P., Tofani V., Gigli G., Casagli N.: Landslide Characterization Using Satellite Interferometry (PSI),

20 Geotechnical Investigations and Numerical Modelling: The Case Study of Ricasoli Village (Italy), International Journal of Geosciences, 4: 904-918, 2013

Rossi G., Nocentini M., Lomabrdi L., Vannocci P., Tanteri L., Dotta G., Bicocchi G., Scaduto G., Salvatici T., Tofani V., Moretti S., Casagli N.: Integration of multicopter drone measurements and ground-based data for landslide monitoring. Landslides and Engineered Slopes. Experience, Theory and Practice - Aversa et al. (Eds), 2016.

25 Tofani V., Segoni S., Agostini A., Catani F., Casagli N.: Technical note: Use of remote sensing for landslide studies in Europe. Nat. Hazards Earth Syst. Sci., 13, 1-12, 2013.

Travelletti J., Delacourt C., Allemand P., Malet J. P., Schmittbuhl J., Toussaint R., Bastard M., Correlation of multi-temporal ground-based optical images for landslide monitoring: Application, potential and limitations ISPRS Journal of Photogrammetry and Remote Sensing 70, 39-55, 2012.

30 Varnes D.J.:Slope movement types and processes. Transportation Research Board Special Report, 176, 1978.

Westoby M.J., Brasington J., Glasser N.F., Hambrey M. J., Reynolds J.M.: ‘Structure-from-Motion' photogrammetry: A low-cost, effective tool for geoscience applications. Geomorphology, 179: 300-314, 2012 
Nat. Hazards Earth Syst. Sci. Discuss., doi:10.5194/nhess-2017-46, 2017

Manuscript under review for journal Nat. Hazards Earth Syst. Sci.

Discussion started: 13 February 2017

(c) Author(s) 2017. CC-BY 3.0 License.

(c) (i)

\section{Natural Hazards and Earth System Sciences \\ Discussions}

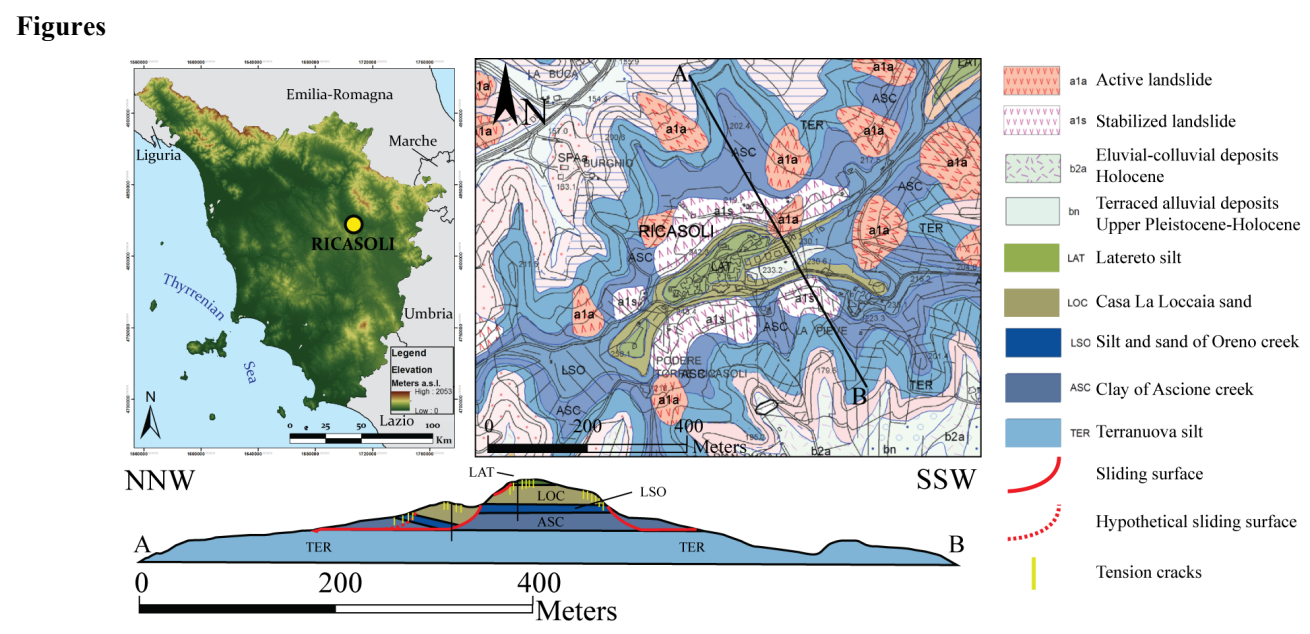

Figure 1: Location, geological map and geological cross section of Ricasoli village (modified after Rosi et al. 2013) 
Nat. Hazards Earth Syst. Sci. Discuss., doi:10.5194/nhess-2017-46, 2017

Manuscript under review for journal Nat. Hazards Earth Syst. Sci.

Discussion started: 13 February 2017

(c) Author(s) 2017. CC-BY 3.0 License.

\section{Natural Hazards and Earth System \\ Sciences \\ Discussions}

(c) (i)
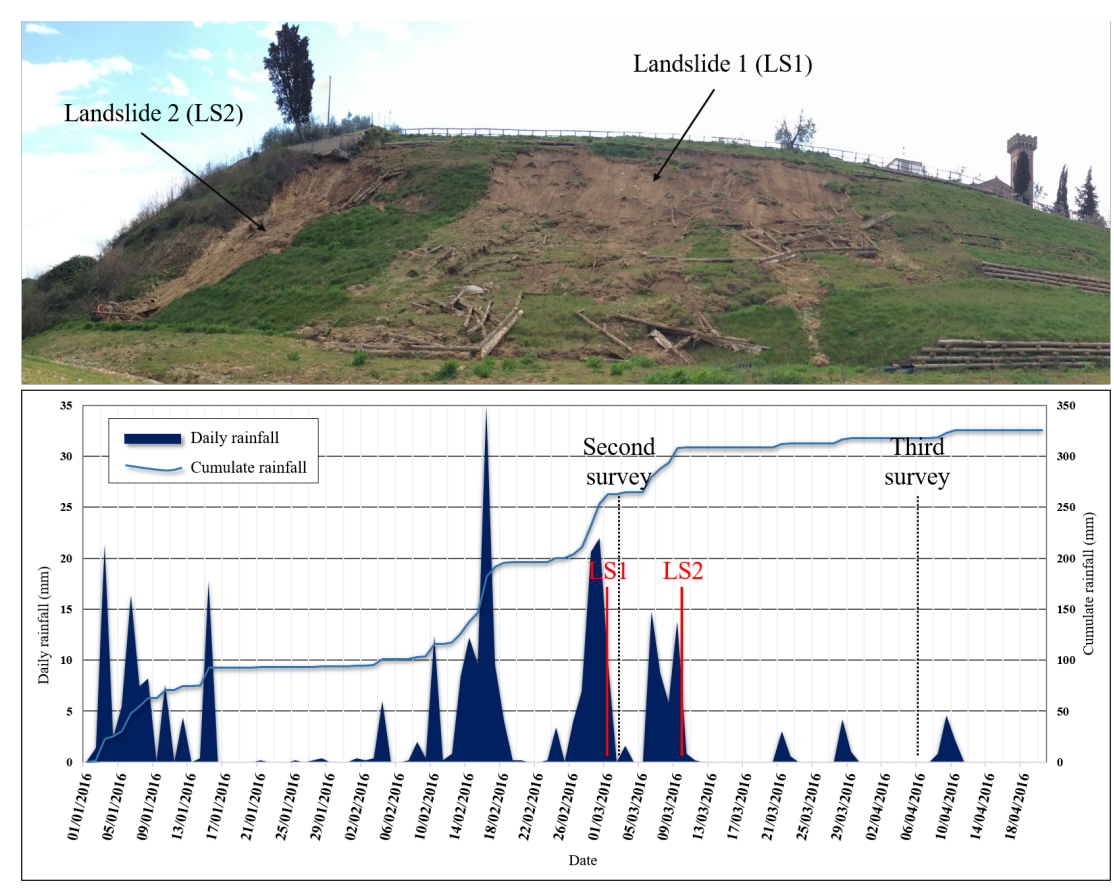

Figure 2: Panoramic view of the portion of the northern slope of Ricasoli affected by the landslides. The plot below shows the temporal occurrence of the two landslides and the survey dates, with respect of daily and cumulated rainfall registered by a nearby rain gauge, from January the $1^{\text {st }} 2016$ to April the $21^{\text {st }} 2016$. 
Nat. Hazards Earth Syst. Sci. Discuss., doi:10.5194/nhess-2017-46, 2017

Manuscript under review for journal Nat. Hazards Earth Syst. Sci.

Discussion started: 13 February 2017

(c) Author(s) 2017. CC-BY 3.0 License.

\section{Natural Hazards and Earth System Sciences \\ Discussions}
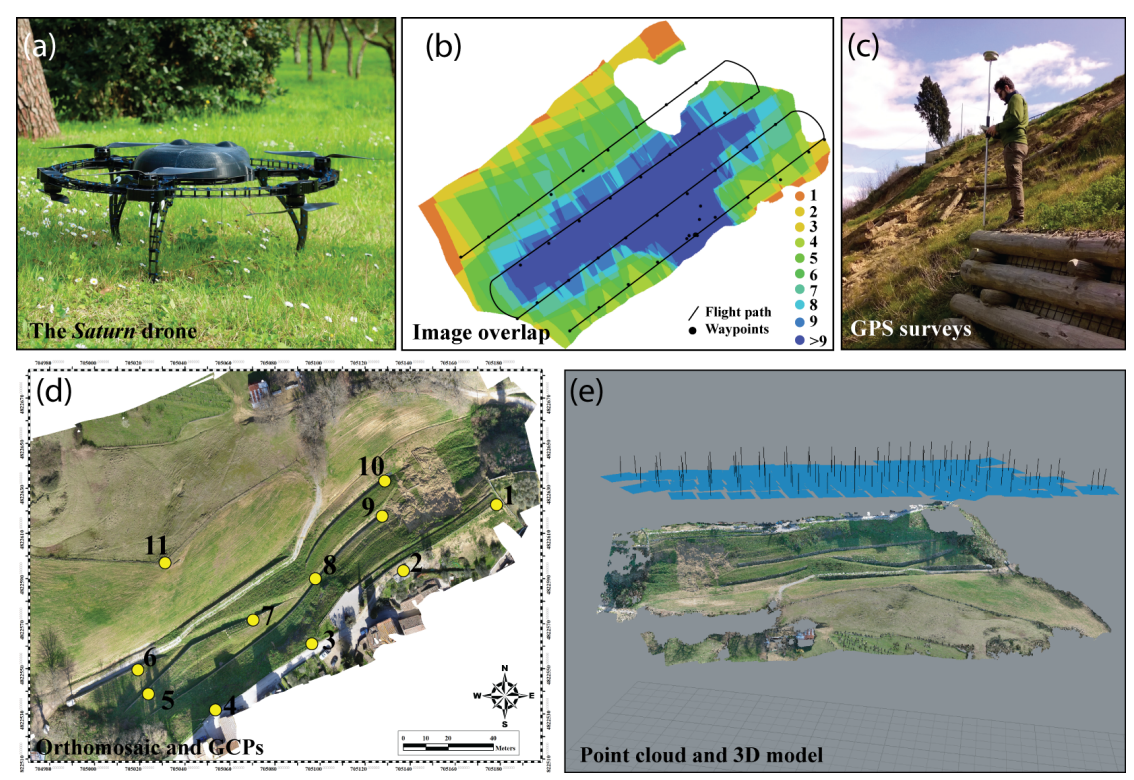

Figure 3: The Saturn drone designed and built by the Department of Earth Science of the University of Florence (a) and stages of photogrammetrical surveying: flight planning; (b) GPS acquisition (c,d), point cloud processing (e). 
Nat. Hazards Earth Syst. Sci. Discuss., doi:10.5194/nhess-2017-46, 2017

Manuscript under review for journal Nat. Hazards Earth Syst. Sci.

Discussion started: 13 February 2017

(c) Author(s) 2017. CC-BY 3.0 License.

\section{Natural Hazards and Earth System Sciences \\ Discussions}

(c) (i)
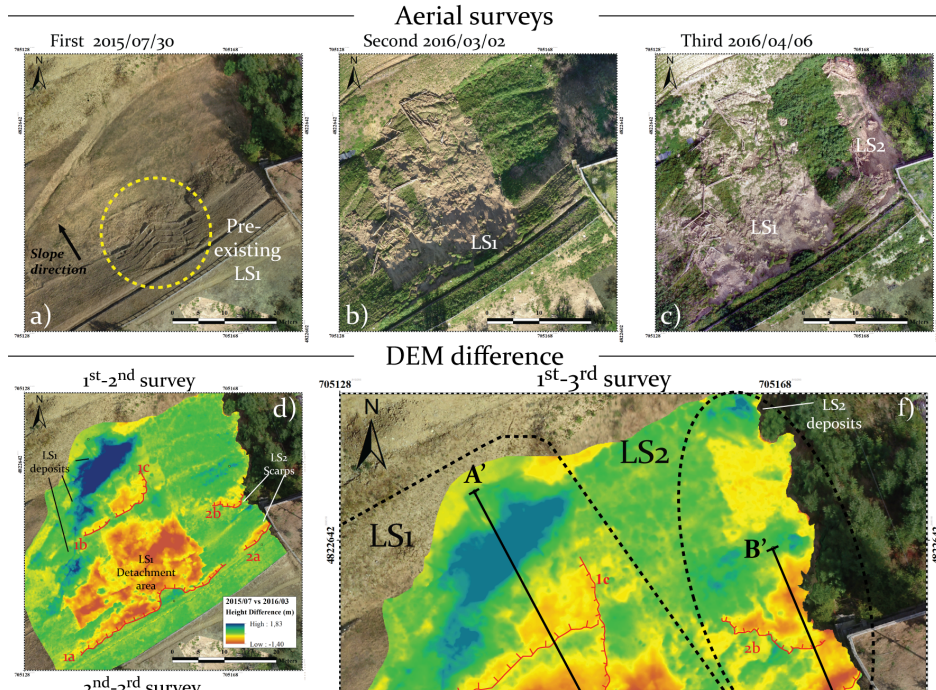

DEM difference
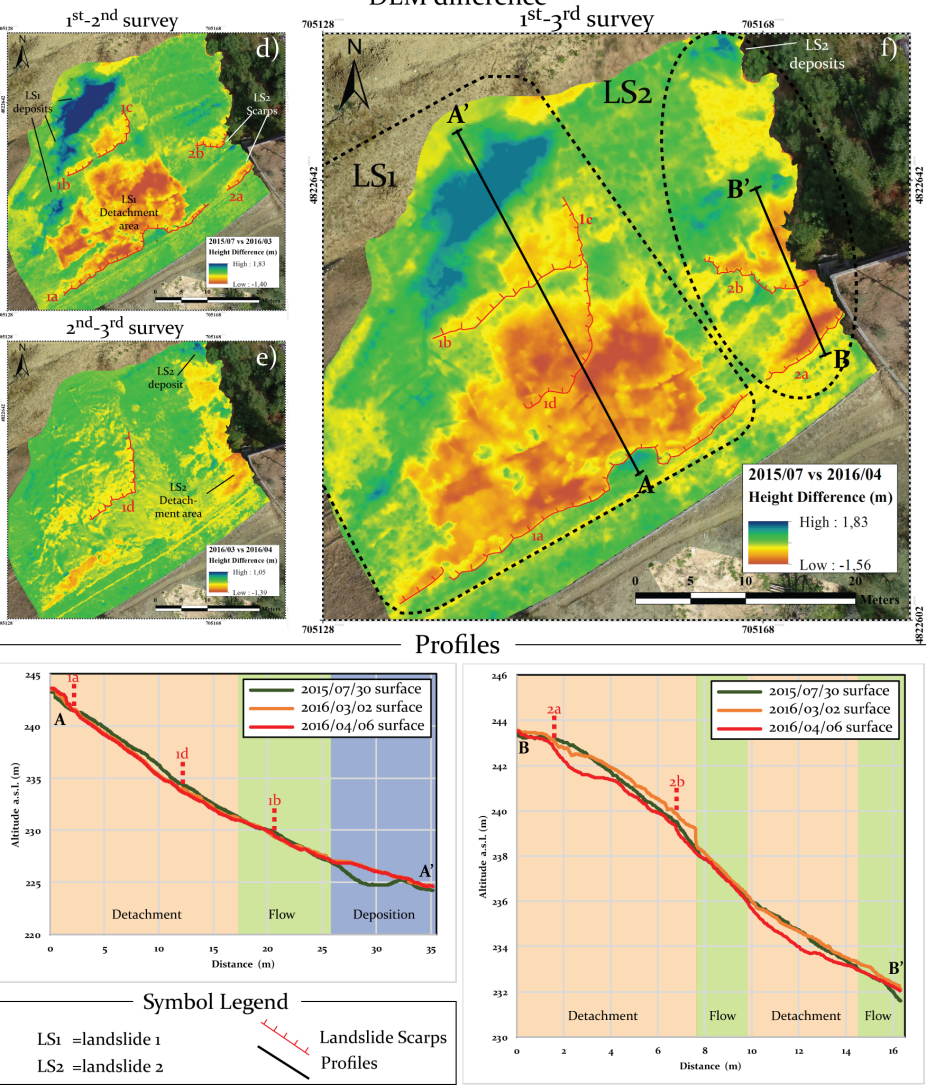

Figure 4: Orthophotos of the area affected by the landslides (a, b, c) and DEM differences among different acquisitions (d, e, f). At the bottom topographical profiles obtained from the three raster surfaces with location of the main scarps. The colours indicate 5 the different zones of the landslides: detachment, flow, and deposition. 
Nat. Hazards Earth Syst. Sci. Discuss., doi:10.5194/nhess-2017-46, 2017

Manuscript under review for journal Nat. Hazards Earth Syst. Sci.

Discussion started: 13 February 2017

(c) Author(s) 2017. CC-BY 3.0 License.

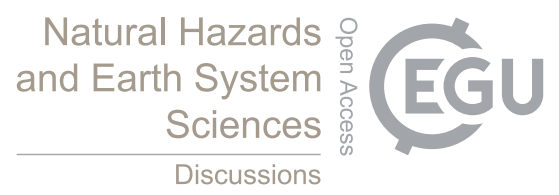

5 Table 1: Data related to the three different surveys.

\begin{tabular}{|l|c|c|c|}
\hline & \multicolumn{3}{|c|}{ MULTICOPTER DRONE SURVEYS } \\
\hline & July 2015 & March 2016 & April 2016 \\
\hline Number of images & 58 & 106 & 45 \\
\hline $\begin{array}{l}\text { Average flying altitude } \\
\text { (m.a.g.1.) }\end{array}$ & 70,6 & 70,3 & 09,7 \\
\hline Ground resolution (m/pix) & 0.019 & 0,02 & 0,019 \\
\hline Number of GCPs & 12 & 18 & 0,0151 \\
\hline Coverage area (km ${ }^{2}$ ) & 0.0186 & 0.0186 & 31910 \\
\hline Number of tie-points & 9328 & 14690 & 160217 \\
\hline Number of projections & 52527 & 96102 & 0,0595 \\
\hline Overall Error in XY (m) & 0,0741 & 0,0475 & 0,0221 \\
\hline Overall Error in Z (m) & 0,0791 & 0,0115 & 0,0635 \\
\hline Overall Error (m) & 0,1085 & 0,0489 & 0,77 \\
\hline Overall Error (pix) & 0.91 & 0,07 & $4,11 \times 10^{7}$ \\
\hline Processed points & $10^{8}$ & $9,96 \times 10^{7}$ & 0.02 \\
\hline $\begin{array}{l}\text { Orthomosaic resolution } \\
\text { (m/pix) }\end{array}$ & 0.02 & 0.02 & 0.02 \\
\hline DEM resolution (m/pix) & 0.02 & 0.02 & \\
\hline
\end{tabular}

